\title{
RADIO ECHO-SOUNDING OF SVALBARD GLACIERS
}

\author{
By Yu. YA. Macheret and A. B. Zhuravlev \\ (Institut Geografii, Akademiya Nauk S.S.S.R., Staromonetny per. 29, 10917 Moskva, U.S.S.R.)
}

\begin{abstract}
Peculiarities of radio echo-sounding of mountain glaciers and ice fields between nunataks from terrestrial vehicles and from helicopters are considered in this paper. The possibility of using comparatively high frequencies (of up to $865 \mathrm{MHz}$ ) for sounding such glaciers is demonstrated on the basis of experimental data. Results of airborne radio echo-sounding of Svalbard glaciers of various types, dimensions, and regime obtained with the help of the $620 \mathrm{MHz}$ airborne equipment of high resolution are shown. Returns from the glacier bed have been obtained on the majority of glaciers under investigation. The firn regions of ice fields with temperate regimes flowing between nunataks are, mostly, an exception. Depression in the glacier bed with the ice thickness up to $540 \mathrm{~m}$, as well as internal reflecting boundaries have been detected in some glaciers. Ice volumes of glaciers have been determined from the airborne radio echo-sounding data with the use of a parabolic approximation to the cross-section glacier profiles. Good correlational dependence between ice volume and surface area of glaciers has been established and is used to estimate the ice and water resources in Svalbard glaciers.
\end{abstract}

RÉSumé. Sondages par écho-radio des glaciers du Svalbard. Dans cet article on examine les particularitės des sondages par écho-radio de glaciers de type de montagne ou de piedmont depuis des véhicules terrestres ou par hélicoptère. Sur la base des données expérimentales on montre une possibilité d'utiliser à titre de comparaison des hautes fréquences (jusqu'à $865 \mathrm{MHz}$ ) pour sonder de tels glaciers. On donne et on discute les résultats de sondages aériens par écho-radio des glaciers du Svalbard de type montagne, piedmont et calotte, avec des appareils de $620 \mathrm{MHz}$ à grande capacité de résolution spatiale. Des signaux réfléchis sur le lit du glacier ont été recueillis sur la majorité des glaciers sondés. Les zones de névés des glaciers de type piedmont avec des régimes thermiques "chauds" (glaciers tempérés) sont, la plupart du temps, une exception. On a découvert sur une série de glaciers des dépressions du fond du lit avec des valeurs de l'épaisseur de glace allant jusqu'à $540 \mathrm{~m}$, ainsi que des plages de réflexion interne. A partir de sondages par écho-radio en utilisant une approximation parabolique pour les profils des sections transversales d'un glacier on a pu déterminer les volumes des glaciers et établir une bonne corrélation avec la surface englacée. On en a tiré une estimation des ressources en glace et en eau des glaciers du Svalbard.

ZuSAMmENFASSUNG. Radar-Echolotungen an Gletschern in Svalbard. Es werden Besonderheiten von RadarEcholotungen über Gebirgs- und Eisstromgletschern mit Landfahrzeugen und Hubschraubern erläutert. Auf der Grundlage experimenteller Ergebnisse lässt sich zeigen, dass relativ hohe Frequenzen (bis zu $865 \mathrm{MHz}$ ) zur Auslotung solcher Gletscher benutzt werden können. Ergebnisse mit Radar-Echolotungen aus der Luft von Gletschern verschiedenen Typs, unterschiedlicher Grösse und Temperaturzustand auf Svalbard mit einem $620 \mathrm{MHz}$ - Gerät hoher Auflösung werden vorgeführt. Von der Mehrzahl der untersuchten Gletscher wurden Signale vom Untergrund erhalten. Die Firngebiete des Eisstromnetzes mit temperiertem Wärmezustand bilden hier meist eine Ausnahme. Sowohl Absenkungen des Bettes bei Eisdicken bis zu $540 \mathrm{~m}$ wie innere Reflexionshorizonte wurden bei einer Reihe von Gletschern festgestellt. Aus den Flugradar-Daten wurden unter Annahme eines annähernd parabolischen Querschnitts Gletschervolumina bestimmt. Dabei ergab sich eine gute Korrelation zur Gletscherfläche, die zur Abschätzung der Eis- und Wasserrücklagen in den Gletschern Svalbards benutzt wurde.

\section{INTRODUCTION}

Almost all the known types of glaciers - from small corrie and valley glaciers to large ice sheets including ice fields with many nunataks, known in Russian as "reticulated glaciers" (a transitional form between mountain glaciers and ice sheets)-are widespread in the Svalbard archipelago. These glaciers have both cold and temperate regimes and various zones of ice formation. They have therefore much in common with glaciers located in the regions of 
mountain glaciation in the temperate zone. The Svalbard glaciers are therefore very suitable for various glaciological investigations.

Until recently ice thickness and sub-ice relief of Svalbard glaciers have been studied less than other parameters of these glaciers. Before 1974 such data were available for some glaciers in three regions of the archipelago: Van Keulenfjorden, Kongsfjorden, and Nordaustlandet (Husebye and others, [1965]; Oelsner, 1966; Ekman, 1971). These data were obtained in Nordaustlandet by seismic measurements, and in the two other regions by means of the less precise gravimetric method. In addition, land-based radio echo-sounding had been performed on a glacier located in the Adventfjord region (Liestøl 1974).

In 1974-75 and 1977-79 radio echo-sounding (RES) of Svalbard glaciers was carried out from helicopters and terrestrial vehicles by an expedition from the Institut Geografii of the U.S.S.R. Akademiya Nauk. Measurements from helicopters were performed on 87 glaciers of various types, dimensions, and regime in regions of mountain, "reticulated", and ice-sheet glaciation, using $440 \mathrm{MHz}$ aircraft radio-altimeter and $620 \mathrm{MHz}$ special equipment. Land RES investigations were carried out on some mountain and "reticulated" glaciers. They included a detailed survey of ice thickness and sub-ice relief and also certain radiophysical measurements in the frequency range of $430-865 \mathrm{MHz}$.

Later, during April-May 1980, British and Norwegian investigators carried out helicopters RES of 45 Spitsbergen glaciers using $60 \mathrm{MHz}$ S.P.R.I. Mk IV equipment designed for deep cold ice in Antarctica and Greenland (Drewry and others, 1980).

The main results of the Soviet RES investigations in Svalbard are considered and analysed in this paper. The peculiarities of RES of mountain and "reticulated" glaciers at different frequencies, and approaches to the creation of special airborne equipment for their study, are also discussed.

\section{PeCUliarities of RADIO ECHO-SOUNDING OF MOUNTAIN AND "RETICUlated” GlaCIERS}

Most important scientific and applied data on ice thickness, sub-ice relief, internal structure, and regime of glaciers and their electrical properties have been obtained on cold ice sheets of Antarctica and Greenland with the help of RES. Pulse radars with carrier frequencies of 30,35 , $60,100,150,213$, and $300 \mathrm{MHz}$ and with total system performance of 130-205 dB have been used there efficiently both for land and airborne measurements (Gudmandsen, [1977], Bogorodskiy and Trepov, 1978). Good results have also been obtained with the help of $440 \mathrm{MHz}$ aircraft radio-altimeters RV-10 and SCR-718 in the coastal parts of the ice sheets including valley glaciers where ice thickness did not exceed 300-900 m (Waite, 1966; Bogorodskiy, 1968; Davis and others, 1973). Investigations at higher frequencies have also been carried out, namely at $700 \mathrm{MHz}$ (Kozlov and Fedorov, 1968).

Since 1966 the RES method has been used to investigate mountain glaciers. The first hopeful results were obtained on some Tyan'-Shan' glaciers from terrestrial vehicles and helicopters using the same $440 \mathrm{MHz}$ equipment (Ryumin, 1967; Ryumin and Zverev, 1969). In 1967 the possibility of RES of temperate mountain glaciers was confirmed by investigations in the Caucasus at the same frequency (Macheret and Sukhanov, 1970). In 1968-74 land RES measurements were carried out in the U.S.S.R. in the Caucasus, the Polar Urals, and in the Pamir-Alay at $440 \mathrm{MHz}$ (Luchininov and Macheret, 1971; Ryumin, 1972, Macheret and Luchininov, 1973; Sukhanov, 1973, Luchininov and others, 1974; Ryumin and others, 1974; Zhuravlev, 1976; Golubev and others, 1978) and also in Norway at $480 \mathrm{MHz}$ (Smith and Evans, 
1972), i.e. in the regions where temperate glaciers are widespread. These investigations showed that interpretation of the results obtained was very complicated and also indicated the necessity of applying special methods and equipment which differ from those used on cold ice sheets. The main difficulty in interpretation of the data obtained on mountain glaciers is caused by great amounts of clutter. This clutter impedes or sometimes excludes the possibility of identifying the useful signals reflected from the bed and/or from internal boundaries directly from the screen of $J$ - and $A$-indicators or on the $Z$-records. Besides, the depth of sounding was limited to the first few hundred metres.

These difficulties are accounted for by certain features in the structure and regime of mountain glaciers as compared to cold ice sheets. Mountain glaciers have higher ice temperature, much water on the glacier surface and inside the glacier, many morainic inclusions, many cavities of various sorts and crevasses, high steep valley walls, and a complex configuration of the upper and lower boundaries. In addition the above-mentioned high-frequency equipment has unsatisfactory parameters: poor space resolution and too low a total system performance.

That is why land measurements with $440 \mathrm{MHz}$ equipment had some special features. First of all, many random samples of reflected signals have been registered in the close vicinity of the sounding points using special instruments. Statistical treatment of these samples has been carried out to identify the signals reflected from the bed despite the clutter background (Sukhanov, 1973; Golubev and others, 1978). Secondly, discrete measurements with a sufficiently small interval have been performed at random or fixed points of the profile during land surveys from moving vehicles; the distance between these points varied from $1 \mathrm{~m}$ to $100 \mathrm{~m}$ (Luchininov and Macheret, 1971; Macheret and Luchininov, 1973; Luchininov and others, 1974; Zhuravlev, 1976). Apart from this, measurements at fixed points have been carried out with different orientations of the receiving and transmitting antennae in the horizontal and vertical planes. Antennae of Yagi type ("wave channel") with a narrower beam width have also been applied to reduce the clutter.

The following main criteria have been used to identify signals reflected from the glacier bed (Luchininov and Macheret, 1972; Macheret and Luchininov, 1973; Sukhanov, 1973): insignificant fluctuations of reflected signals in travel time when shifting the installation or when moving the antennae apart at distances from a few centimetres to several metres, as well as when changing the orientation of the antennae in a horizontal plane; regular change of travel time of reflected signals when shifting the installation along the sounding profile by a distance of the order of several hundred metres. Comparison of the data obtained by RES and thermo-drilling of certain investigated glaciers has shown that the use of such methods and criteria for the identification of signals reflected from the bed provides RES measurements of the ice thickness of satisfactory accuracy.

For various reasons, the mentioned methods are, however, either unfit or inefficient for airborne measurements. A more efficient way is to increase the signal-to-noise ratio and thus obtain a more useful signal-to-clutter ratio. It is possible to attain this mainly by the choice of optimum equipment parameters, such as carrier frequency, length and the shape of transmitted pulse, receiver band-width and dynamic range of the receiver, beam width of antennae, and the total system performance of the radar. More efficient systems of continuous registration of reflected signals, in particular $Z$-recording with prior differentiation of detected signals, may then be used.

In 1972-74 land tests of special equipment designed for RES of temperate glaciers were carried out. Good results at frequencies of $620 \mathrm{MHz}$ and 1-5 MHz were obtained on Athabasca Glacier in Canada (Goodman, 1973) and on South Cascade Glacier in U.S.A. (Watts and 
others, 1975). Later, similar modified equipment was also successfully applied on other glaciers in Canada, U.S.A., and Iceland (Goodman, 1975; Goodman and others, 1975; Clarke and Goodman, 1975; Björnsson and others, 1977; Miller, 1979).

The transition to higher frequencies made it possible to use antennae with a narrow beam width, in this case of $5.2^{\circ}$ in one of the planes. Discrete measurements in the regime of $A$-recording with two mutually perpendicular positions of the receiving-transmitting antenna were carried out to distinguish the signals reflected from the bed, from internal inhomogeneities, from roughnesses of glacier surface, and from valley slopes.

The use of lower frequencies, as Watts and England (1976) have shown, brought about a decrease in clutter background caused by the scattering in intraglacial inhomogeneities and crevasses. Because of the large dimensions of antennae working at these frequencies, these measurements were taken only from the glacier surface, including from vehicles.

In 1974-75 a lot of RES measurements from a helicopter were carried out on Spitsbergen mountain and "reticular" glaciers, using the $440 \mathrm{MHz}$ radio-altimeter RV-17 with a total system performance of about $130 \mathrm{~dB}$ (Macheret, 1976[a], [b]; Macheret and Zhuravlev, 1980). The half-wave vibrators with flat reflectors (from the RV-17 set) having a broad beam width were used. Reflected signals were recorded with Z-indicator on $35 \mathrm{~mm}$ film.

These investigations have shown that the equipment allowed sounding of the Spitsbergen mountain and "reticulated" glaciers with ice thicknesses up to $150-250 \mathrm{~m}$ even during the ablation period. But returns from the bed of thicker "reticulated" glaciers were recorded with great gaps. The zones with gaps increased during periods of intensive melting on the glaciers. Under these conditions the identification of the signals reflected from the bed was considerably impeded, as reflections from internal boundaries were recorded on some glaciers at depths from $70 \mathrm{~m}$ to $180 \mathrm{~m}$, and returns from valley slopes were also often recorded.

The analysis of results of airborne RES, and also of some special land RES investigations, has shown that it is expedient to obtain measurements from Svalbard glaciers before the beginning of melting season. In Svalbard the best time is the period from March to May. The total system performance of a radar should be increased up to $185-195 \mathrm{~dB}$ in order to increase the sounding depth of Svalbard glaciers up to 500-600 m and to decrease the probability of incorrect interpretation of results. The beam width of the antennae should also be narrowed considerably. Thus, special equipment is required.

Such equipment was designed during 1976-77 in the Mariyskiy Politeknicheskiy Institut im. M. Gorkiy in cooperation with the Institut Geografii. The choice of an optimum carrier frequency was one of the most complicated problems since a whole number of contradictory requirements have to be taken into consideration.

As has already been mentioned, the efficiency of a radar greatly depends on the clutter level and on the sounding depth. These characteristics, in their turn, are determined by the effects of scattering, absorption, and total attentuation of electromagnetic energy, as well as by the features of glaciers' structure and regime. These problems are considered in detail in several papers (Bogorodskiy, 1968; Fedorov, 1969; Robin and others, 1969; Smith and Evans, 1972; Robin, 1975; Watts and England, 1975; Vasilenko and others, 1980; etc.). Absorption in cold ice sheets is practically independent of frequency up to $500 \mathrm{MHz}$, but absorption increases at higher frequencies and also with increasing temperature. The scattering on intraglacial inhomogeneities (cavities, water inclusions, ice layers, and ice lenses of different density, etc.) also increases at higher frequencies and rises when the concentration and size of inhomogeneities increase. Besides, if sizes of glacier bed roughnesses are comparable with the wavelength, the 
reflecting coefficient is decreased because of scattering. Therefore, sufficiently high signal-tonoise ratio and useful signal-to-clutter ratio can only be reached at lower frequencies. But the antenna dimensions grow at lower frequencies, which makes the mounting of antennae on aircraft or helicopters more difficult. However, the simplest types of antennae with acceptable dimensions cannot ensure large antenna gain and narrow beam width. On the other hand, it is possible to reduce scattering losses and to increase space radar resolution by generating short pulses and using an antenna with a narrow beam width. However, this is possible, if comparatively high frequencies are used. Application of higher frequencies permits a decrease of the antenna dimensions and leads to the growth of absorption, scattering, and total attenuation. The latter increases substantially, if there is melt water or wet snow or firn on the glacier surface. But experimental data on the total attenuation in mountain and "reticulated" glaciers with temperate and cold temperature regime over a broad frequency range are lacking.

In 1976 and 1977 experimental investigations in the ablation region of the temperate glaciers Lednik IGAN and Lednik Obruchev in the Polar Urals, and in the accumulation region of transection glaciers Austre Grønfjordbreen and Fridtjovbreen in Spitsbergen, were carried out to select the carrier frequency and antenna design of aircraft-mounted radar (Vasilenko and others, 1980; Macheret and others, 1980). The measurements were carried out using special equipment working in the 150 to $930 \mathrm{MHz}$ frequency range.

Logoperiodical vibrator antennae were used to measure the total attenuation of returns. Amplitudes of signals reflected from the bed were determined, first at discrete frequencies at the points where the signals were maximum, and, secondly, during depolarization measurements. An experimental dependence of the total attenuation $\mathrm{N}_{\Sigma}$ of these signals obtained on Spitsbergen in the frequency range 430 to $740 \mathrm{MHz}$ is given on Figure 1. This dependence has oscillations (the cause of these oscillations is not discussed here), but the mean observed values of the total attenuation (see curve 3 on Fig. 1a) markedly increase at frequencies above $620 \mathrm{MHz}$. A similar dependence has also been obtained on Polar Urals glaciers, although there the losses were somewhat higher. Hence, it follows that frequencies less than $620 \mathrm{MHz}$ are more desirable for RES of such glaciers.

If, using a simple electrophysical model of a homogeneous isotropic glacier with plane and parallel mirror boundaries, we exclude "geometrical" losses (arising from wave-front divergence, focusing factor, and reflections from the upper and lower boundary of a glacier) from curve 3 on Figure 1a, generalised specific losses $\bar{\Pi}_{\Sigma}$ (stipulated for absorption in the ice and for scattering on inhomogeneities in the glacier and roughness on its boundaries) can be evaluated from the resulting differential curve since depolarizational losses, according to our measurements, are small and do not exceed $3 \mathrm{~dB}$. As seen from Figure $1 \mathrm{~b}, \bar{\Pi}_{\Sigma}$ linearly increases at frequencies above $640 \mathrm{MHz}$. In the range $640-740 \mathrm{MHz}$ the frequency dependence is

$$
\bar{\Pi}_{\Sigma}=(2.2+0.0115 f) \mathrm{dB} / 100 \mathrm{~m}
$$

where $f$ is the frequency in $\mathrm{MHz}$. At lower frequencies $\bar{\Pi}_{\Sigma}$ values practically are independent of the frequency and equal about $6 \mathrm{~dB} / 100 \mathrm{~m}$. This value is more than the values of absorption losses measured on ice samples at temperatures very close to the melting point (see, for example, Bogorodskiy, 1975; Glen and Paren, 1975).

Measurements undertaken on the ice divide of Austre Grønfjordbreen-Fridtjovbreen at frequencies of 786 and $865 \mathrm{MHz}$ have shown that the maximum depth of sounding at these frequencies by radar with a total system performance of about $120 \mathrm{~dB}$ is equal to $178 \mathrm{~m}$ and $163 \mathrm{~m}$, respectively. These results are in good agreement with evaluations made with values of 

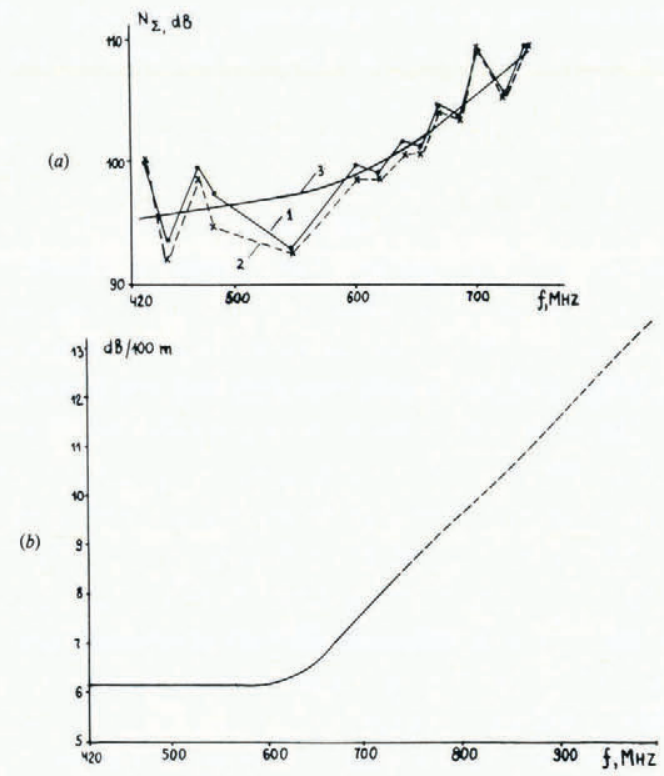

Fig. 1. Dependence of the total attenuation $N_{\Sigma}$ of signals reflected from the bed (a) and of generalized specific losses $\bar{\Pi}_{\Sigma}$ (b) upon frequency $f$. Measurements on the ice divide of glaciers Austre Gronfjordbreen-Fridtjovbreen, Spitsbergen, 1977. 1 and 2-data from measurements of the maximum amplitudes of reflected signals observed at every fixed frequency by small shifts of the measuring installation and by rotating the receiving antenna in the horizontal plane, 3 - the curve obtained by averaging the experimental data.

$\bar{\Pi}_{\Sigma}$ extrapolated according to Figure $1 \mathrm{~b}$ into the range of higher frequencies. Apparently, such an extrapolation is valid for frequencies of at least $1000 \mathrm{MHz}$.

Results obtained testify to the fact that high frequencies of up to $700-900 \mathrm{MHz}$ or even $1000 \mathrm{MHz}$ are usable for sounding mountain and "reticulated" glaciers with relatively small ice thickness, and also for the study of the structure and regime of the upper part of these glaciers. The recent information about the successful use of radar operated at $840 \mathrm{MHz}$ for airborne RES of small mountain glaciers in Canada confirms this conclusion (Narod and Clarke, 1980).

Various types of antennae were also tested in the frequency range of $150-930 \mathrm{MHz}$ in the Polar Urals glaciers. In particular, the following antennae were used: antennae of the "triple square" type with almost symmetric beam width (for frequencies of $150,240,380,440,620$, and $930 \mathrm{MHz}$ ), logoperiodical vibrator antennae (for $150-450 \mathrm{MHz}$ and $400-1000 \mathrm{MHz}$ ), halfwave dipoles with plane reflectors (for $440 \mathrm{MHz}$ ), as well as antennae with two half-wave dipoles and corner reflector with "fan" beam width (for $440 \mathrm{MHz}$ ). It has been established that narrowing of the antenna beam-width in both planes (for antennae of the "triple square" type) improves the quality of the results, whereas narrowing of the antenna beam width in one of plane only gives weak effects if continuous survey from moving vehicles with constantly oriented antennae is employed.

However, simple antennae of the above-mentioned types having a large beam width are less efficient for airborne RES of small mountain glaciers because of the possibility of recording returns from nearby valley slopes. An antenna with a narrow beam-width proves to be more efficient. Calculations have shown (Vasilenko and others, 1980), that an antenna grid consisting 


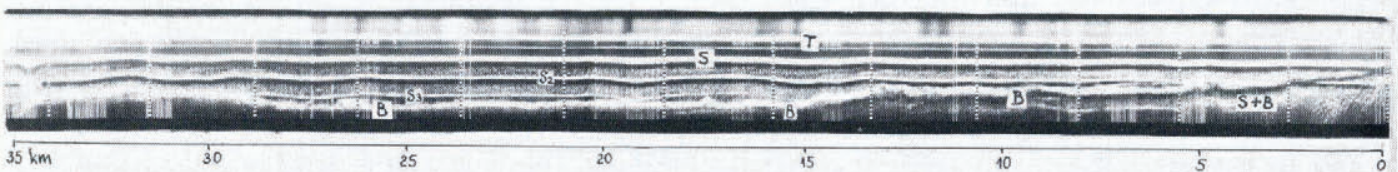

Fig. 2. An example of the Z-record obtained by airborne radio echo-sounding of Veteranen in the north-east of Spitsbergen. The flight was performed along the axis of the glacier. $T$-transmitted pulses, $S$ - signals reflected from the glacier surface, $B$-signals reflected from the glacier bed, $S_{2}$ and $S_{3}$-two-and three-fold reflected signals from the glacier surface, $S+B$-over-reflections from the surface and bed of the glacier. Solid vertical lines denote moments of flying over landmarks, dotted vertical lines denote time marks. Distance between neighbouring marks in the horizontal plane corresponds to $60 \mathrm{~s}$, in the vertical plane corresponds to $0.5 \mu \mathrm{s}$.

of 16 elements of the "triple square" type at a frequency of about $600 \mathrm{MHz}$ will have a beam with of nearly $18^{\circ}$ in both planes, forward gain of about $18 \mathrm{~dB}$, and dimensions of $1.5 \mathrm{~m} \times$ $1.5 \mathrm{~m} \times 0.3 \mathrm{~m}$ which allows us to mount this antenna under the fuselage of a helicopter.

In 1977 field tests of a working model of the airborne $620 \mathrm{MHz}$ equipment with such a 16element antenna grid were performed on Svalbard (Macheret and others, 1980). They proved that this approach to the design of airborne equipment is quite promising.

In 1978-79 a modified airborne RLS-620 with a carrier frequency of $620 \mathrm{MHz}$ was designed and applied for RES of Svalbard glaciers. The antennae had a beam width of about $18^{\circ}$ and the total system performance of the radar was $185 \mathrm{~dB}$. Recording of reflections could be done both continuously, from the screen of the $Z$-indicator, and discretely, from the screen of the $A$ indicator, there being a possibility for differentiation of the detected received signals.

An example of a $Z$-record obtained on the glacier Veteranen is given in Figure 2. Apart from the transmitted pulse (T), and the signals reflected from the surface (S) and from the bed (B), there are also the two- and three-fold reflections from the surface $\left(S_{2}\right.$ and $\left.S_{3}\right)$, and complex overreflected signals from the surface and the bed $(\mathrm{S}+\mathrm{B})$. The over-reflected signals are clearly distinguished in the record due to their regular nature although they could mask useful returns from the bed and internal reflecting layers when there was a coincidence in travel time. One can see from Figure 2 that the signals reflected from the bed are traced almost continuously even when the ice thickness reaches $500 \mathrm{~m}$.

The use of RLS- 620 radio echo equipment allowed us to make the sounding depth of a "reticulated" glacier on Svalbard 2-3 times as large, as compared with the $440 \mathrm{MHz}$ radioaltimeter (the maximum ice thickness measured was $540 \mathrm{~m}$ ), and to obtain simply interpretable records of reflected signals. Signals reflected from the bed were recorded on a great majority of glaciers studied, among them those in the regions of "reticulated" and ice-sheet glacierization. Some of these regions, mainly accumulation areas of glaciers and of glacier complexes as well as some zones of crevasses, were an exception (Kotlyakov and others, 1980).

\section{Ice thickness and sub-ice relief of the Svalbard glaciers}

During five field seasons, RES has been carried out on 87 Svalbard glaciers, including side tributaries and outlet glaciers, of various types, dimensions, and regime. These glaciers are located in the western, north-western, north-eastern, and south-western parts of Spitsbergen and in the west of Nordaustlandet (Fig. 3). The total length of airborne RES profiles was about $2000 \mathrm{~km}$. Detailed land RES measurements were also performed on Brøggerbreen, Vøringbreen, 
and Bogerbreen, as well as on the ice divide of glaciers Austre GrønfjordbreenFridtjovbreen and on Fridtjovbreen. Measurements on Austre Grønfjordbreen and Fridtjovbreen were carried out near two bore holes, which were bored in 1975 (Zagorodnov and Zotikov, 1981) and in 1979 and provided ice cores to depths of $211 \mathrm{~m}$ and $119 \mathrm{~m}$ respectively, in order to compare data from RES and thermal drilling. The first of the bore holes reached the bed. The second one went down to a depth of about $220 \mathrm{~m}$ without ice core, but did not reach the bed. The other land RES was performed to obtain detailed maps of ice thickness and of sub-ice relief of glaciers. These data are required to study the fluctuations of glaciers. They were also used for the determination of ice volume and water resources of glaciers and for evaluation of the accuracy of the data obtained by airborne RES.

Measurements from helicopters were usually carried out along the longitudinal axis of glaciers. The altitude of flights over the glacier surface was within $100-300 \mathrm{~m}$, the flight speed was from $80-120 \mathrm{~km} / \mathrm{h}$ to $160-200 \mathrm{~km} / \mathrm{h}$. Position of the flight lines was determined visually with the help of Norsk Polarinstitutt maps with the scales of 1:100 000 and 1:500 000 and using typical landmarks of the locality. Glacier tongues and fronts, some moraines, nunataks, etc. usually served as such landmarks. Repeated airborne RES along the same flight lines and also flights over glaciers where land RES measurements had been carried out, were used to evaluate the accuracy of the flight route determination. Comparison of results of repeated airborne RES as well as of airborne and land RES showed that such a method provides reliable data on ice thickness and sub-ice relief of glaciers along the flight routes. Differences in ice thickness of the eight glaciers up to $12.5 \mathrm{~km}$ long investigated most comprehensively in the western part of the Spitsbergen did not exceed $60 \mathrm{~m}$ and were on average 10-30 m. Accuracy of determination of flight route is, however, insufficient for detailed mapping of the ice thickness and sub-ice relief of glaciers.

An error of RES measurements of ice thickness, as compared to the thermodrilling data on the ice divide of Austre Grønfjordbreen-Fridtjovbreen, is about $4 \%$, the value accepted for calculation is $C_{\mathrm{i}}=168 \mathrm{~m} / \mu$ s where $C_{\mathrm{i}}$ is the mean velocity of propagation of radio waves in a glacier. Comparison of the data on thermodrilling and on land-based RES performed for the profile network $50 \mathrm{~m} \times 50 \mathrm{~m}$ in the region of this bore hole, has shown that the value $C_{\mathrm{i}}=161.4 \pm 3 \mathrm{~m} / \mu \mathrm{s}$ (Macheret and others, 1980).

Radio echo measurements in the second bore hole on Fridtjovbreen down to depth of about $145 \mathrm{~m}$ give the value $C_{\mathrm{i}}=165.9 \pm 3 \mathrm{~m} / \mu \mathrm{s}$. These values are close to the velocity of $168 \mathrm{~m} / \mu \mathrm{s}$ which was used for further calculations and for plotting of profiles of glaciers along the flight routes and the land-survey lines. The methods of reconstruction of subglacial relief worked out by Harrison (1970) and Luchininov (1977) were considered in detail by Macheret and Zhuravlev (1980), Berikashvili and Macheret (1980).

In general, the results obtained from the airborne RES can be divided into three groups on the basis of the degree of information about the sub-ice bed (in percentages): $40-100 \%, 5-20 \%$ and $0 \%$. The majority of the glaciers investigated-about $85 \%$, all the mountain glaciers among them-belong to the first group. About $10 \%$ of the glaciers belong to the second group. On these glaciers, signals reflected from the bed were observed, as a rule, near the glacier ends, borders, or nunataks, but they disappeared in the accumulation areas and near the ice divide part of glacier complexes where ice thicknesses exceeded 200-300 m. On glaciers of the first group the gaps in signals reflected from the bed on radio echo records were also mainly observed in these parts. Accumulation areas of glacier systems in the "reticulated" glacierization regions belong to the third group. These are Isachsenfonna in Haakon VII Land, as well as Amundsenisen, 


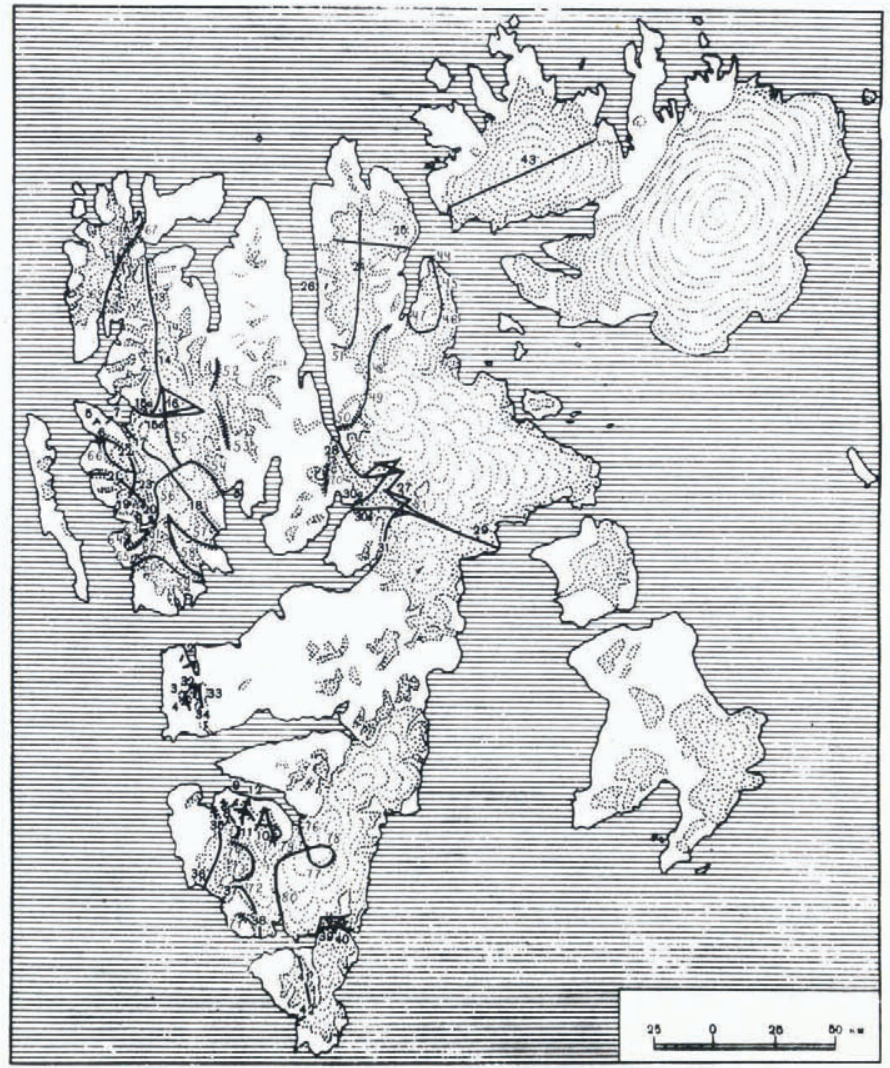

Fig. 3. Radio echo-sounding of the Svalbard glaciers during 1974-75 and 1977-79. Lines show the routes of the airborne radio echo-sounding. Mountain glaciers: 1-Aldegondabreen, 2-Voringbreen, 3-Dahlfonna, 4-Erdmannbreen, 5-Austre Broggerbreen, 6-Vestre Broggerbreen, 7-Midre Lovénbreen, 8-Antoniabreen, 9-Hessbreen, 10-Penckbreen, with tributaries Suessbreen and Tirolarbreen (in the east). 11 -Sveisarfonna, 12-Finsterwalderbreen with tributaries Revtannbreen (in the west) and Leinbreen (in the east), 70-Bertilbreen; "reticulated" glaciers: 13-Monacobreen, 14-Isachsenfonna, 15a-Kongsbreen, $15 b$-Kronebreen, 16-Holtedahlfonna, 17-Kongsvegen, 18-Sveabreen, 19-Dahlbreen, 20-Konowbreen, 21-Aavatsmarkbreen, 22-Uversbreen, 23-Løvenskioldfonna, 24-Asgårdfonna, 25-Valhallfonna, 26-Sørbreen, 27-Lomonosovfonna, 28-Mittag-Lefflerbreen, 29-Negribreen, 30-Nordenskiøldbreen, northern (a) and southern (b) flows; 31-Tunabreen, 32-Vestre Grønfjordbreen, 33-Austre Grønfjordbreen, 34-Fridtjovbreen, 35-Recherchebreen, 36-Vestre Torellbreen, 37-Austre Torellbreen, 38-Hansbreen, 39-Hornbreen, 40-Hambergbreen, 41-Samarinbreen, 42-Olsokbreen, 44-Odinjøkulen, 45-Torsfonna, 46-Balderfonna, 47-Kantbreen, 48-Veteranen, 49-Månebreen, 50-Stubendorfbreen, 51-Cookbreen, 52-Elnabreen, 53-Orsabreen, 54-Sefstrømbreen, 55-Holmstrømbreen, 56-Osbornebreen, 57-Wahlenbergbreen, 58-Borebreen, 59-Nansenbreen, 60-Eidembreen, 61-Løvliebreen, 62-Vestgøtabreen, 63-Holmesletbreen, 64-Skipperbreen, 65-Hydrografbreen, 66-Comfortlessbreen, 67-Idabreen, 68-Raudfjordbreen, 69-Lilliehøøkbreen, 71-Werenskiøldbreen, 72-Vrangpeisbreen, 73-Amundsenisen, 74-Høgstebreen, 75-Bjørnbreen, 76-Nathorstbreen, 77-Ljosfonna, 78-Dobrowolskibreen, 79-Pollakbreen, 80-Muhlbacherbreen, 81-Opalbreen; ice sheets: 43-Vestfonna (Nordaustlandet). Types of the glaciers are given in accordance with classification derived from the work by Troitskiy and others (1975). 

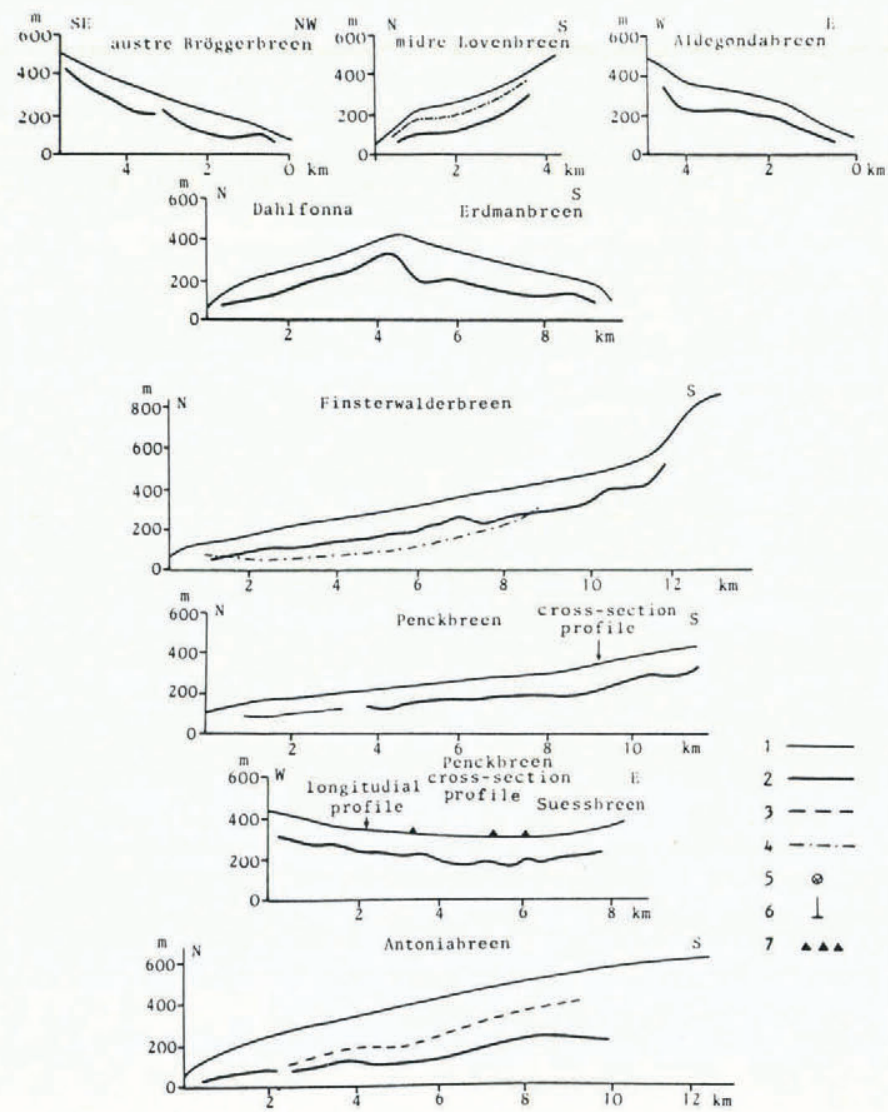

Fig. 4. Profiles of typical mountain glaciers on Spitsbergen by airborne radio echo-sounding data. I-the glacier surface, 2 and 3-the glacier bed and internal reflecting boundary by the airborne radio echo-sounding data, 4- the glacier bed from gravity measurements, 5- the glacier bed from the data of seismic measurements of the Swedish expedition in 1958 (Ekman, 1971), 6-thermoboring bore holes, 7-the medial moraines. See Figure 3 for the position of the profiles.

Vrangpeisbreen, Høgstebreen, Dobrowolskibreen, Ljosfonna in the southern part of Spitsbergen where ice thicknesses also exceed 200-300 m.

Heavy scattering and absorption of electromagnetic energy in the upper wet snow and firn layer and in temperate ice is the most probable cause of the absence of signals reflected from the bed. Considerable increase in the total attenuation can also be related to the great ice thicknesses of these glaciers. Among other causes there also may be: a water layer on the glacier surface (for example, in the zone of formation of superimposed ice), low reflection coefficient from the lower boundary due to its great roughness or to the presence of a matching layer and the large inclination of the bed. And finally, it can be small ice thicknesses not exceeding the resolution of radar in distance (45-65 $\mathrm{m}$ deep in the ice).

As has been already noted, very significant scattering and absorption are typical for temperate glaciers. Isachsenfonna and a number of the glaciers in the western part of Spitsbergen 


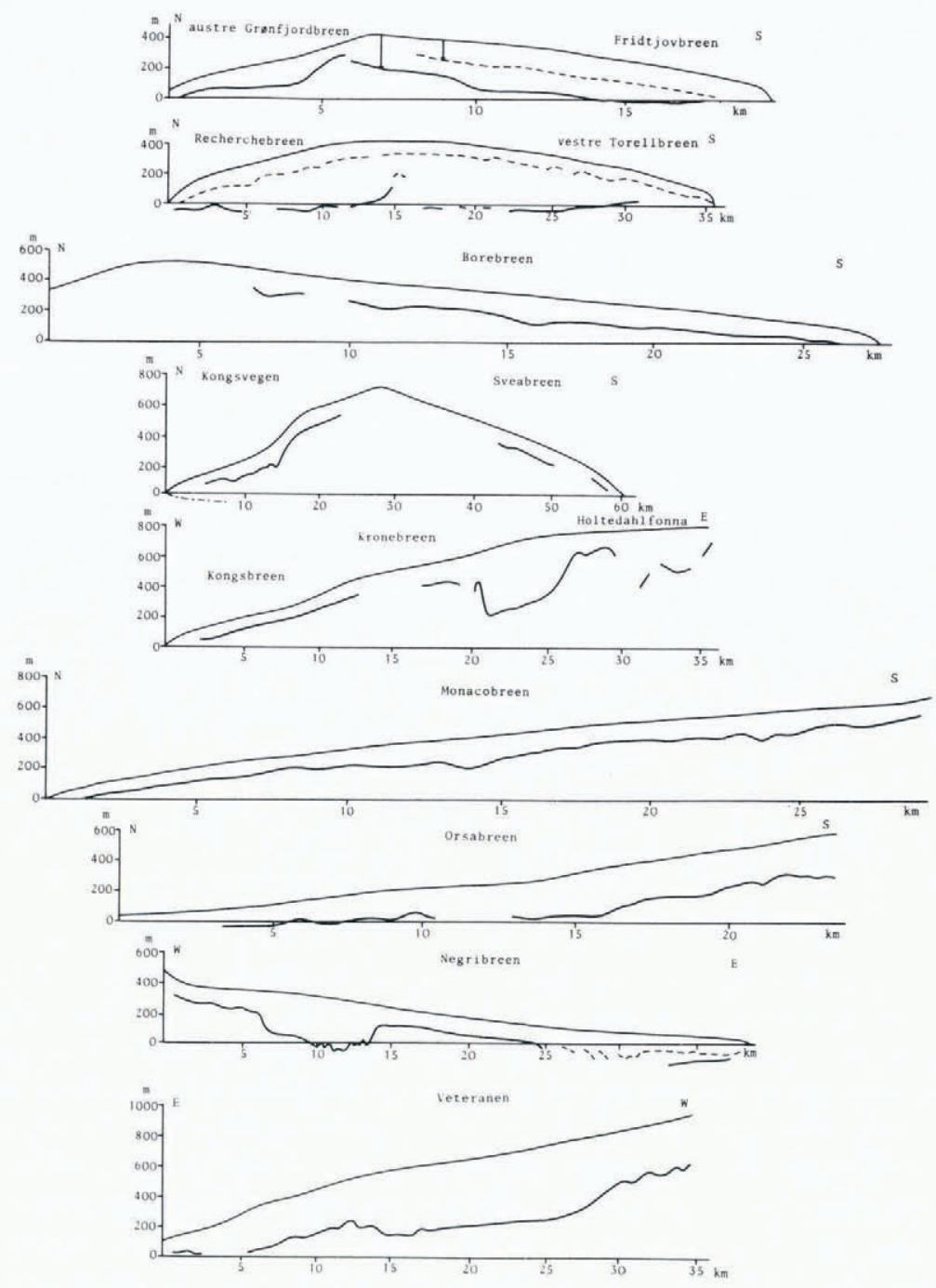

Fig. 5. Profiles of typical "reticulated" glaciers on Spitsbergen occupying negative land forms from the airborne radio echo-sounding data. Symbols are the same as in Figure 4.

belong to such glaciers (Troitskiy and others, 1975). Most of the glaciers of the second and third groups also belong to such glaciers.

The Svalbard glaciers, according to the classification given by Troitskiy and others (1975), are subdivided into four main morphological types: (1) mountain glaciers, (2) "reticulated" glaciers occupying negative landforms, (3) "reticulated" glaciers occupying positive landforms, (4) ice sheets. This classification is also used in our paper. Cross-section profiles of typical Svalbard glaciers of these types are given in Figures 4, 5, and 6. Maximum ice thickness of some investigated glaciers are given in Table I. 

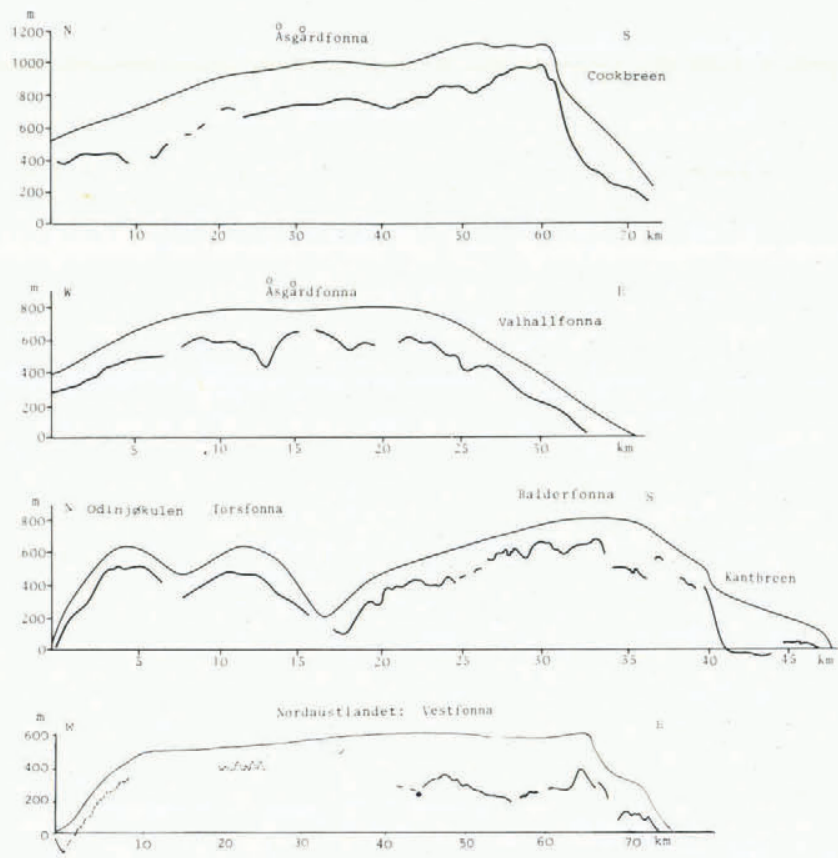

Fig. 6. Profiles of typical "reticulated" glaciers occupying positive land forms, and of an ice sheet on Svalbard by airborne radio echo-sounding data. Symbols are the same as in Figure 4.

Glaciers of the first type. Valley glaciers Austre Brøggerbreen, Midre Lovenbreen, and Finsterwalderbreen have the maximum ice thickness of 135,150 , and $175 \mathrm{~m}$, respectively. On Austre Brøggerbreen in the vicinity of the firn line there is a sub-ice Riegel of about $100 \mathrm{~m}$ high. This Riegel is also clearly visible on the maps of ice thickness and of sub-ice relief (Fig. 7), compiled from the land-based survey data of 1974 (Macheret, 1976[b]). Results of land-based and airborne RES of ice thickness agree well with the data of gravimetric surveys carried out in 1975 by the scientists from the Norsk Polarinstitutt (personal communication from D. Bjørkedal and J. Gjessing in 1975). However, ice thicknesses of Finsterwalderbreen and Midre Lovénbreen determined from airborne RES data are in certain sections almost half and in others almost as large as the ice thicknesses obtained from the data from gravimetric measurements of 1963 and 1964 (see Husebye and others, [1965]; Oelsner, 1966, and Figure 4). Aldegondabreen has ice thicknesses of up to $150 \mathrm{~m}$. The longitudinal profiles of the glaciers Dahlfonna and Erdmannbreen are not symmetrical; Erdmannbreen of south-west aspect has greater dimensions and greater ice thickness reaching $210 \mathrm{~m}$ in the area of the ice divide. The ice thickness of the larger Antoniabreen which has also been classified by V. S. Koryakin (see Troitskiy and others, 1975) as a glacier of mountain type, reaches $350 \mathrm{~m}$. The bed of the glacier is relatively flat, its inclination is about $2^{\circ}$. The nearby surging glacier Hessbreen is about $100 \mathrm{~m}$ thick in its lower part, its bed is comparatively smooth and is steeper, the bed inclination is about $5^{\circ}$. The ice thickness of Penckbreen reaches $150 \mathrm{~m}$ on a longitudinal profile. It is noteworthy that the position of medial moraines on the transverse profile coincides with small cones of the glacier bed, i.e. the medial moraines have so-called "roots" on the glacier bed. 
TABle I. Area $F$, volume $V$ and the maximum MEASured thickness $h_{\max }$ of Certain Svalbard Glaciers

\begin{tabular}{|c|c|c|c|c|c|c|c|}
\hline Glaciers & $F$ & $V$ & $h_{\max }$ & Glaciers & $F$ & $V$ & $h_{\max }$ \\
\hline Glaciers of type I & $\mathrm{km}^{2}$ & $\mathrm{~km}^{3}$ & $\mathrm{~m}$ & Glaciers of type 2 & $\mathrm{~km}^{2}$ & $\mathrm{~km}^{3}$ & $\mathrm{~m}$ \\
\hline Aldegondabreen & 10.3 & 0.71 & 150 & Kantbreen & 24.9 & 3.74 & 330 \\
\hline Antoniabreen & 32 & 4.00 & 350 & Kongsvegen & 140 & 7.80 & 165 \\
\hline Bertilbreen & 6.0 & 0.44 & 140 & Løvliebreen & 11 & 1.09 & 165 \\
\hline Bogerbreen & 4.5 & 0.30 & 145 & Mittag-Lefflerbreen & 190 & 32.30 & 540 \\
\hline Brøggerbreen, Austre & 13.3 & 0.76 & 135 & Nansenbreen & 47 & 3.28 & 120 \\
\hline Brøggerbreen, Vestre & 5.6 & 0.24 & 95 & Negribreen & 553 & 101.82 & 385 \\
\hline Dahlfonna & 9.8 & 0.86 & 110 & Nordenskiöldbreen, sth. & 130 & 10.92 & 165 \\
\hline Erdmannbreen & 11.2 & 1.41 & 210 & Orsabreen & 56 & 9.94 & 315 \\
\hline Finsterwalderbreen & 38 & 2.80 & 175 & Recherchebreen & 82 & 24.06 & 430 \\
\hline Hessbreen & 7.2 & 0.46 & 115 & Sefströmbreen & 110 & 18.36 & 205 \\
\hline Leinbreen & 4.1 & 0.31 & 110 & Skipperbreen & 3.6 & 0.26 & 165 \\
\hline Lovénbreen, Midre & 5.8 & 0.37 & 150 & Stubendorffbreen & 55 & 7.69 & 260 \\
\hline Märjelbreen & 6.4 & 0.47 & 120 & Sveabreen & 174 & 8.54 & 140 \\
\hline Penckbreen & 83 & 8.85 & 150 & Torellbreen, Vestre & 217 & 59.16 & 430 \\
\hline Revtannbreen & 5.9 & 0.29 & 125 & Tunabreen & 77. & 3.56 & 125 \\
\hline Suessbreen & 9.0 & 0.54 & 130 & Uversbreen & 74 & 6.65 & 165 \\
\hline \multirow[t]{2}{*}{ Vøringbreen } & 2.1 & 0.13 & 120 & Vestgötabreen & 12.6 & 1.26 & 145 \\
\hline & & & & Veteranen & 165 & 24.41 & 500 \\
\hline Glaciers of type 2 & & & & Wahlenbergbreen & 96.6 & 12.88 & 195 \\
\hline Aavatsmarkbreen & 54 & 3.60 & 120 & Werenskioldbreen & 34 & 3.00 & 320 \\
\hline Bjørnbreen & 34.9 & 2.43 & 165 & & & & \\
\hline Borebreen & 120 & 13.32 & 185 & Glaciers of type 3 & & & \\
\hline Cookbreen & 18 & 3.52 & 310 & Ảsgårdfonna & 1740 & 190.95 & 350 \\
\hline Eidembreen & 103 & 9.65 & 145 & Balderfonna & 418 & 26.89 & 330 \\
\hline Elnabreen & 8.9 & 0.61 & 180 & Foxfonna* & 14.8 & 0.51 & 120 \\
\hline Fridtjovbreen & 63 & 10.62 & 320 & Odinjøkulen & 58 & 2.27 & 120 \\
\hline Grønfjordbreen, Austre & 12.1 & 0.75 & 210 & Torsfonna & 83 & 4.31 & 215 \\
\hline Grønfjordbreen, Vestre & 36.4 & 2.82 & 165 & Valhallfonna & 410 & 43.09 & 350 \\
\hline Hansbreen & 72 & 11.91 & 330 & & & & \\
\hline Holmesletbreen & 2.4 & 0.14 & 150 & Glaciers of type 4 & & & \\
\hline Holmstrømbreen & 77 & 6.10 & 210 & Austfonnat & 8020 & 1120.03 & 520 \\
\hline Hydrografbreen & 12.8 & 0.80 & 110 & Vestfonnat; & 2670 & 357.87 & 385 \\
\hline Idabreen & 11.4 & 0.78 & 100 & & & & \\
\hline
\end{tabular}

* From data of land-surface radio echo-sounding (Liestøl, 1974).

† From data of seismic sounding (Ekman, 1971).

† From data of seismic sounding (Ekman, 1971) and of airborne radio echo-sounding.

Glaciers of the second type. Transection glaciers Austre Grønfjordbreen and Fridtjovbreen occupy a valley divided by a subglacial Riegel about $200 \mathrm{~m}$ high. The maximum ice thicknesses of these glaciers approach $210 \mathrm{~m}$ and $320 \mathrm{~m}$ respectively. The sub-ice water divide of the glacier valley is somewhat displaced northwards as compared to the ice divide of the glaciers; the bottom of the Fridtjovbreen lies near or below sea-level in its lower part over an area of several kilometres. Glaciers Recherchebreen-Vestre Torellbreen are up to $430 \mathrm{~m}$ thick and occupy a through valley. The bottom of these glaciers mostly lies below sea-level. The bottom rises above sea-level for only $200 \mathrm{~m}$ in the ice divide section, near the nunataks. The valley glacier Borebreen, being typical of Oscar II Land, has ice thicknesses of up to $185 \mathrm{~m}$ and a relatively even bed, which is almost parallel to the glacier surface.

In the north of Spitsbergen, transection glaciers have comparatively high ice divides 


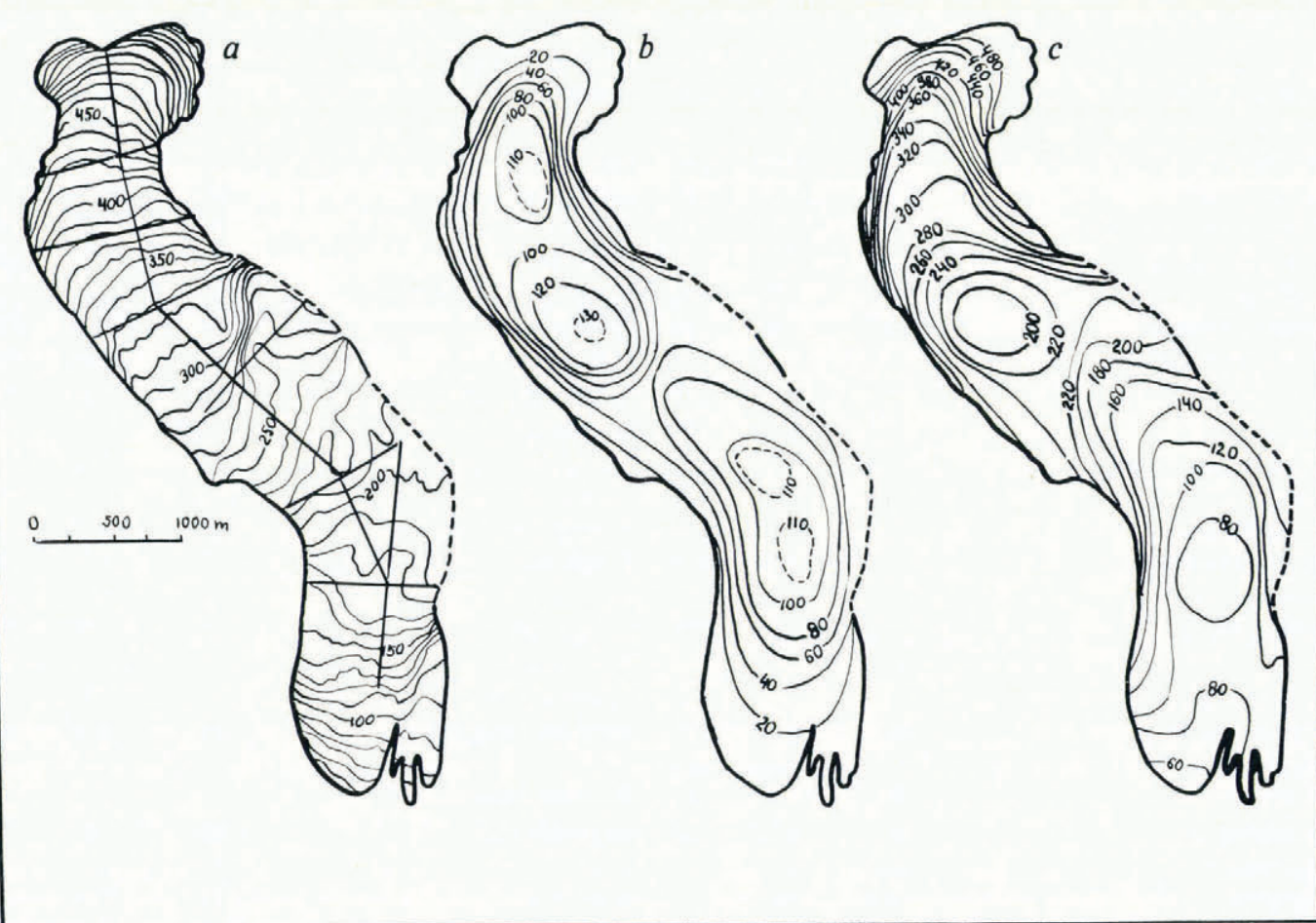

Fig. 7. Ice thickness and sub-ice relief of.the glacier Austre Brøggerbreen from land-based radio echo-sounding data. $a$-profiles of measurements (Macheret, 1976/b]), b-ice thickness, $c$ - sub-ice relief.

—around $750 \mathrm{~m}$ on Kongsvegen-Sveabreen and almost $850 \mathrm{~m}$ on MonacobreenKronebreen-Kongsbreen. Returns from the bed were not obtained in the ice divide sections. According to the data available, ice thickness in the lower parts of these glaciers does not exceed 200-250 m, and sub-ice relief is rather smooth there. However, airborne RES data in the lower part of the glacier Kongsvegen differ greatly from results of gravimetric measurements of 1964 (see Oelsner, 1966, and Fig. 5). In the upper part of Kronebreen and on Holtedahlfonna two depressions in the bed have been discovered. The ice thicknesses in these areas reach $440 \mathrm{~m}$, exceeding the surrounding thicknesses by $200-300 \mathrm{~m}$. Orsabreen, the glacier draining from Holtedahlfonna, has an ice thickness of $315 \mathrm{~m}$. Depressions in the bed have also been discovered on Mittag-Lefflerbreen and on Negribreen flowing from Lomonosovfonna. The ice thicknesses here reach $540 \mathrm{~m}$ and $385 \mathrm{~m}$, respectively, exceeding the surrounding values by $200-400 \mathrm{~m}$. On Negribreen we can also observe an abrupt submergence of the bed from the point of $+100 \mathrm{~m}$ down to a point $-180 \mathrm{~m}$ below sea-level and a very irregular internal reflecting boundary. The profile obtained for this glacier in its lower part is very similar to the profile of the ice shelf. Veteranen, located north-eastward of Lomonosovfonna, has ice of great thickness, reaching up to $500 \mathrm{~m}$ in its middle part.

Glaciers of the third type. The ice cap Åsgårdfonna with Valhallfonna abutting as well as Odinjøkulen, Torsfonna, and Balderfonna belong to this type of glacier. According to airborne 
RES data, sub-ice relief in the centre of Åsgårdfonna (on the transverse profile) and of Balderfonna is extremely rough, ice thickness varies from $100 \mathrm{~m}$ to $300-350 \mathrm{~m}$ over a distance of several kilometres. On the other hand, sub-ice relief of Odinjøkulen and Torsfonna, as well as Åsgårdfonna (on the longitudinal profile) is rather even. Ice thickness varies there from $120-215 \mathrm{~m}$ to $320 \mathrm{~m}$. The bedrock topography of all the ice caps has positive landforms and consists of spreading domes. Ice thicknesses of the outlet glaciers Kantbreen in the north of Balderfonna and Cookbreen in the west of Åsgårdfonna reach $330 \mathrm{~m}$ and $310 \mathrm{~m}$ respectively.

Glaciers of the fourth type. Vestfonna in the western part of Nordaustlandet is one of the glaciers of this type. Sub-ice relief of Vestfonna is highly rough in its coastal parts, but it is probably rather smooth in the central part of the ice sheet, where ice thickness reaches $385 \mathrm{~m}$. It should be noted, that results of airborne RES are in good agreement with the data obtained by seismic measurements in 1958 (Ekman, 1971).

In general, new radio echo-sounding data allow us to identify a regular decrease in ice thicknesses from the south to the north in the western part of Spitsbergen and a westward decrease in its northern part. Evidently, this phenomenon is associated with the prevailing direction of the moist air streams and with the reduction of precipitation, and with it accumulation, on glaciers in the directions just noted, as well as with features of geological and tectonic structure of the island.

\section{INTERNAL STRUCTURE AND ICE VOLUME OF THE SVALBARD GLACIERS}

An internal reflecting boundary has been discovered on some of the glaciers investigated (Fridtjovbreen, Recherchebreen, Vestre Torellbreen, Antoniabreen, Negribreen, etc.) (see Fig. 5 and also Macheret, 1981). According to the data of some investigators (see Baranowski, 1978), the glaciers Fridtjovbreen, Recherchebreen, and Negribreen were surging. In Baranowski's opinion (Baranowski, 1978), one of the possible causes of glacier surges on Svalbard is the difference in temperature regime and rheological properties between the upper colder ice layer and the lower temperate one in the glacier tongues.

On Fridtjovbreen internal reflections have been also observed by land-based RES on the cross-section profile near the $211 \mathrm{~m}$ deep bore hole at a depth of $70 \mathrm{~m}$, as well as on the $2 \mathrm{~km}$ long section of the longitudinal profile at a distance of $1 \mathrm{~km}$ from this bore hole, at depths of 100-130 m (Macheret and Zhuravlev, 1980; Macheret and others, 1980). The depth and shape of the internal reflecting boundary obtained from land and airborne RES data are very similar.

Layers of transparent and impure ice within bubbly ice were observed in the ice core from the $211 \mathrm{~m}$ bore hole at depths of $50-85 \mathrm{~m}, 102-106 \mathrm{~m}$, and 145-149 m (Zagorodnov and Zotikov, 1981). Theoretically, it is known that internal reflections on glaciers can be caused by differences in dielectric constant and/or in loss tangent of ice layers which differ in density, impurity content (dust, ashes, etc.), and in structure (ice crystal orientation, content and size of air bubbles in the ice) from the rest of the glacier ice. Similar internal reflections have been often observed in Antarctica and Greenland (Bogorodskiy, 1975; Paren and Robin, 1975; Gudmandsen, 1975; Clough, 1977; Ackley and Keliher, 1979). It is most probable that they are associated with internal layers which were formed in the past during periods of climatic warming (Robin and others, 1969; Whillans, 1976). However, internal reflections can also be associated with other causes, for instance with differences in water content of the ice, with the presence of water and of morainic material within glacier ice, etc. Until now the most probable cause of the internal reflections observed on Fridtjovbreen and the other Svalbard glaciers mentioned above 


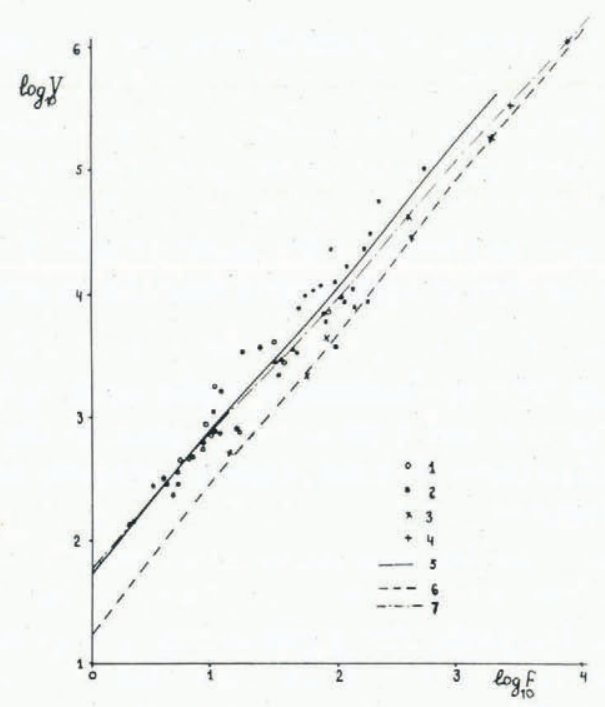

Fig. 8. Correlation between ice volume $V$, in units of $10^{6} \mathrm{~m}^{3}$, of the Svalbard glaciers of various types and their surface area $F$, in $\mathrm{km}^{2}, 1$-mountain glaciers (type 1), 2- "reticulated" glaciers occupying negative landforms (type 2), 3- "reticulated" glaciers occupying positive landforms (type 3), 4-ice sheets (type 4); correlation dependences: 5 - for glaciers of types 1 and 2, 6-for glaciers of types 3 and 4, 7— for glaciers of all types.

has not been finally established, but we hope that the special investigations carried out in 1979 on Fridtjovbreen inside and near the bore hole will help to solve this problem to a certain degree. According to the preliminary data, the internal reflecting boundary discovered near this bore hole at a depth of about $115 \mathrm{~m}$ is associated with the fact that glacier ice with a small content of water (about $1-2 \%$ in volume) appears at depths below about $115 \mathrm{~m}$.

As a rule, the cross-section of mountain and "reticulated" glaciers is close to parabolic in shape. We can determine the ice volume of a glacier, as well as its water equivalent, if the ice density is known, using a parabolic approximation to the upper and the lower boundaries of a glacier in cross-section and knowing the coordinates of three points of every parabola (at the ends and the middle of the transversal profile - at the point of intersection with the longitudinal measurement profile) using maps and airborne RES data (Zhuravlev, 1980). To evaluate the accuracy of this method, the ice volumes of three glaciers (Austre Brøggerbreen, Vøringbreen, and Bogerbreen) have been determined from the data of their land-based RES surveys. Differences did not exceed $8 \%$. Ice volumes of 59 Svalbard glaciers of various types have been determined by this method (Table I) using the airborne RES data which are presented in detail in another paper (Macheret, 1981).

Correlation dependence of ice volume $V$, in units of $10^{6} \mathrm{~m}^{3}$, of these glaciers upon their area $F$, in $\mathrm{km}^{2}$, is depicted logarithmically in Figure 8. This dependence has the form: $\log _{10} V=$ $1.776+1.120 \log _{10} F$, correlation coefficient being $r=0.981$. For glaciers of the types 1 and 2 this dependence is expressed in the following form: $\log _{10} V=1.724+1.180 \log _{10} F$, while for glaciers of the types 3 and 4 it has the somewhat different form: $\log _{10} V=1.232+1.248 \log _{10} F$. The ratio of the mean ice thickness $h=V / F$ to the maximum ice thickness $h_{\max }$ for glaciers of types 1 and 2 is 0.51 with a standard deviation of \pm 0.13 , but this ratio is $0.29 \pm 0.05$ for glaciers of the 3 and 4 types. 
These relations were used to evaluate ice and water resources on Svalbard using the areas of glaciers measured from the above-mentioned maps (Table II). These relations can also be useful for palaeoglaciological reconstructions and calculation of changes in dimensions of the Svalbard glaciers due to climatic changes.

\section{Conclusion}

Experimental investigations have shown that comparatively high frequencies-from $600 \mathrm{MHz}$ to $900 \mathrm{MHz}$ and probably even to $1000 \mathrm{MHz}$ - can be used for radio echo-sounding of mountain and "reticulated" glaciers. These frequencies allow us to design equipment with high space resolution. At frequencies less than $620 \mathrm{MHz}$ total losses from scattering and absorption are less that at higher frequencies, therefore frequencies up to $620 \mathrm{MHz}$ are preferable for RES of thicker glaciers. Still higher frequencies can be used for radio echo-sounding of thinner glaciers and for the studies of internal structure and regime of the upper part of glaciers.

Taking this into consideration, special airborne equipment with carrier frequency of $620 \mathrm{MHz}$, a total system performance of $185 \mathrm{~dB}$, and a narrow antenna beam-width (about $18^{\circ}$ in both the planes) has been developed and successfully applied to airborne RES of Svalbard glaciers. Such a narrow beam-width is provided by a 16-element antenna grid which, due to its relatively small dimensions, can be mounted under the fuselage of a helicopter.

With the help of this equipment, signals reflected from the bed have been obtained on the majority of the Svalbard glaciers investigated from a helicopter in regions of mountain, "reticulated", and ice-sheet glacierization. The success rate of sub-ice relief surveys, as a rule, was over $40 \%$. Depressions in the glacier bed have been detected in some glaciers; ice thicknesses in these hollows reached $540 \mathrm{~m}$ and exceeded the surrounding values by some $200-400 \mathrm{~m}$. It was also discovered that the beds of some glaciers are lower than the sea-level, Internal reflections from depths of $70-180 \mathrm{~m}$ have also been observed on some glaciers. These glaciers have ice thicknesses of more than $250-300 \mathrm{~m}$, and some of them, in the opinion of certain authors, are surging. However, the nature of the internal reflections on all these glaciers has not been explained. This question requires further studies.

However, reflections from the bed have not been obtained in some regions of "reticulated" glacierization, mostly in accumulation areas and in the ice divide sections of temperate glaciers where ice thicknesses exceeded 200-300 m. Increased scattering on inhomogeneities in snow and

TABle II. Areas of glaciers $F_{\Sigma}$, ice volume $V_{\Sigma}$ and Water Resources $W_{\Sigma}$ on Svalbard

\begin{tabular}{lrrr} 
Region & \multicolumn{1}{c}{$\begin{array}{c}F_{\Sigma} \\
\mathrm{km}^{2}\end{array}$} & $\begin{array}{c}V_{\Sigma} \\
\mathrm{km}^{3}\end{array}$ & $\begin{array}{c}W_{\Sigma}^{*} \\
\mathrm{~km}^{3}\end{array}$ \\
Spitsbergen & 24539 & 2305 & 2074.5 \\
Nordaustlandet & 11236 & 1512 & 1360.8 \\
Edgeøya & 2112 & 178 & 160.2 \\
Barentsøya & 608 & 60 & 54.0 \\
Kvitøya & 225 & 15 & 13.5 \\
Prins Karls Forland & 71 & 11 & 9.9 \\
Other islands & 54 & 1 & 0.9 \\
Svalbard (total) & 38845 & 4082 & 3673.8 \\
* Assuming the ice density $\rho_{\mathrm{i}}=900 \mathrm{~kg} / \mathrm{m}^{3}$. & &
\end{tabular}


firn - water inclusions, intercalations and lenses of ice-seems to be the most probable cause of this phenomenon. The problem of airborne RES of temperate glaciers, especially in their accumulation areas, demand further attention.

The method of determination of volume of glaciers from airborne radio echo-sounding data considered in this paper, has rather a high accuracy. Obtained correlational dependences of ice volume of glaciers upon their area can be used for the World atlas of snow and ice resources at present in preparation, in particular for the estimate of the ice and water resources, and also for palaeoglaciological reconstructions and forecasts.

MS. received 1 July 1980 and in revised form 6 May 1981

\section{REFERENCES}

Ackley, S. F., and Keliher, T. E. 1979. Ice sheet internal radio-echo reflections and associated physical property changes with depth. Journal of Geophysical Research, Vol. 84, No. B10, p. 5675-80.

Baranowski, S. 1978 Podvizhki lednikov Shpitsbergena kak klimaticheski obuslovlennoye yavleniye [Surges of Spitsbergen glaciers as features related to climate]. Materialy Glyatsiologicheskikh Issledovaniy. Khronika. Obsuzhdeniya, Vyp. 33, p. 103-06. [Discussion, p. 124. English version, p. 168-70, 184-85.]

Berikashvili, V. Sh., and Macheret, Yu. Ya. 1980. Resheniye dvumernoy obratnoy zadachi radiolokatsionnoy s"yemki tolshchiny l'da i podlednogo rel'yefa gornykh lednikov s pomoshch'yu EVM [Solution of two-dimension feed-back task of radio echo-sounding survey of thickness of the ice and of sub-ice relief of mountain glaciers with the help of computers]. Materialy Glyatsiologicheskikh Issledovaniy. Khronika. Obsuzhdeniya, Vyp. 37, p. 131-39.

Björnsson, H., and others. 1977. A 1976 radio echo sounding expedition to the Vatnajökull ice cap, Iceland, by H. Björnsson, R. L. Ferrari, K. J. Miller, and G. Owen. Polar Record, Vol. 18, No. 115, p. 375-77.

Bogorodskiy, V. V. 1968. Fizicheskiye metody issledovaniya lednikov [Physical methods of investigating glaciers]. Leningrad, Gidrometeoizdat.

Bogorodskiy, V. V. 1975. Radiozondirovaniye l'da [Radio echo-sounding of ice]. Leningrad, Gidrometeoizdat.

Bogorodskiy, V. V., and Trepov, G. V. 1978. Issledovaniye lednikovogo pokrova Antarktidy metodami radiolokatsionnogo zondirovaniya [Investigations of the Antarctic ice sheet with the help of radio echo-sounding methods]. Informatsionnyy Byulleten' Sovetskoy Antarkticheskoy Ekspeditsii, No. 97, p. 104-23.

Clarke, G. K. C., and Goodman, R. H. 1975. Radio echo soundings and ice-temperature measurements in a surgetype glacier. Journal of Glaciology, Vol. 14, No. 70, p. 71-78.

Clough, J. W. 1977. Radio-echo sounding: reflections from internal layers in ice sheets. Journal of Glaciology, Vol. 18 , No. 78 , p. 3-14.

Davis, J. L., and others. 1973. Radio echo sounding on a valley glacier in East Greenland, by J. L. Davis, J. S. Halliday, and K. J. Miller. Journal of Glaciology, Vol. 12, No. 64, p. 87-91.

Drewry, D. J., and others. 1980. Airborne radio echo sounding of glaciers in Svalbard, by D. J. Drewry, O. Liestøl, C. S. Neal, O. Orheim, and B. Wold. Polar Record, Vol. 20, No. 126, p. 261-66.

Ekman, S. R. 1971. Seismic investigations on the Nordaustlandet ice caps. Geografiska Annaler, Vol. 53A, No. 1, p. $1-13$.

Fedorov, B. A. 1969. Radiolokatsionnyye issledovaniya lednikovogo pokrova Antarktidy [Radio echo-sounding investigations of the Antarctic ice sheet]. Trudy Sovetskoy Antarkticheskoy Ekspeditsii, Tom 49, p. 213-38.

Glen, J. W., and Paren, J. G. 1975. The electrical properties of snow and ice. Journal of Glaciology, Vol. 15, No. 73, p. $15-38$.

Golubev, G. N., and others. 1978. Lednik Dzhankuat (Tsentral'nyy Kavkaz) [Lednik Dzhankuat (central Caucasus)]. [By] G. N. Golubev, M. B. Dyurgerov, V. A. Markin, B. L. Berri, L. A. Sukhanov, Ye. A. Zolotarev, A. V. Danilina, Yu. G. Arutyunov. Leningrad, Gidrometeoizdat. (Vodnoledovyy i Teplovoy Balans Gornolednikovykh Rayonov.)

Goodman, R. H. 1973. Time-dependent intraglacier structures. Journal of Glaciology, Vol. 12, No. 66, p. 512-13.

Goodman, R. H. 1975. Radio echo sounding on temperate glaciers. Journal of Glaciology, Vol. 14, No. 70, p. 57-69.

Goodman, R. H., and others. 1975. Radio soundings on Trapridge Glacier, Yukon Territory, Canada, by R. H. Goodman, G. K. C. Clarke, G. T. Jarvis, S. G. Collins, R. Metcalfe. Journal of Glaciology, Vol. 14, No. 70, p. $79-84$. 
Gudmandsen, P. 1975. Layer echoes in polar ice sheets. Journal of Glaciology, Vol. 15, No. 73, p. 95-101.

Gudmandsen, P. [1977.] Studies of ice by means of radio echo sounding. (In Peel, R. F., and others, ed. Remote sensing of the terrestrial environment. Proceedings of the twenty-eighth Symposium of the Colston Research Society, held in the University of Bristol, April 5th to 9th, 1976. Edited by R. F. Peel, L. F. Curtis, and E. C. Barrett. London, etc., Butterworths, p. 198-211.)

Harrison, C. H. 1970. Reconstruction of subglacial relief from radio-echo sounding records. Geophysics, Vol. 35 , No. 6, p. 1099-115.

Husebye, E. S., and others. [1965.] The determination of the thickness of Finsterwalderbreen, Spitsbergen, from gravity measurements, by E. S. Husebye, A. Sørnes, and L. S. Wilhelmsen. Norsk Polarinstitutt. Arbok, 1963, p. 129-36.

Kotlyakov, V. M., and others. 1980. Geofizicheskiye i isotopnyye issledovaniya lednikov Shpitsbergena [Geophysical and isotopic investigations of Spitsbergen glaciers]. [By] V. M. Kotlyakov, Yu. Ya. Macheret, F. G. Gordiyenko, A. B. Zhuravlev. Vestnik Akademii Nauk SSSR, 1980, No. 4, p. 132-38.

Kozlov, A. I., and Fedorov, B. A. 1968. Radiolokatsionnoye zondirovaniye antarkticheskikh lednikov letom $1967 / 1968 \mathrm{gg}$. [Radio echo-soundings of Antarctic glaciers in the summer of 1967-68]. Informatsionnyy Byulleten' Sovetskoy Antarkticheskoy Ekspeditsii, No. 71, p. 53-57.

Liestøl, O. 1974. Glaciological work in 1972. Norsk Polarinstitutt. Arbok, 1972, p. 125-35.

Luchininov, V. S. 1977. Radiolokatsionnoye zondirovaniye i yego primeneniye v glyatsiologii [Radio echo-sounding and its application in glaciology]. (In Losev, K. S., ed. Geofizicheskiye metody $v$ glyatsiologii. Moscow, Vsesoyuzny Institut Nauchnoy i Tekhnicheskoy Informatsii, p. 87-192. (Itogi Nauki i Tekhniki Glyatsiologiya, Tom 1.))

Luchininov, V. S., and Macheret, Yu. Ya. 1971. Elektromagnitnoye zondirovaniye teplykh gornykh lednikov [Electromagnetic sounding of temperate mountain-type glaciers]. Zhurnal Tekhnicheskoy Fiziki, Tom 41, No. 6, p. 1299-309.

Luchininov, V. S., and Macheret Yu. Ya. 1972. Interpretatsiya dannykh radiolokatsionnogo zondirovaniya teplykh gornykh lednikov [Data interpretation from radio echo-sounding of temperate mountain-type glaciers]. Materialy Glyatsiologicheskikh Issledovaniy. Khronika. Obsuzhdeniya, Vyp. 20, p. 195-200.

Luchininov, V. S., and others. 1974. Radiolokatsionnoye zondirovaniye teplykh gornykh lednikov [Radio echosounding of temperate mountain-type glaciers]. [By] V. S. Luchininov, Yu. Ya. Macheret, V. N. Rudakov, V. K. Khmelevskoy. Trudy Zakavkazskogo Nauchno-issledovatel'skogo Gidrometeorologicheskogo Instituta, Vyp. 58 (64), p. 211-24.

Macheret, Yu. Ya. 1976[a]. Izmereniye tolshchiny lednikov [Measurement of the thickness of glaciers]. Priroda, 1976, No. 10, p. 90-91.

Macheret, Yu. Ya. 1976[b]. Nekotoryye rezul'taty radiolokatsionnogo zondirovaniya lednikov Zapadnogo Shpitsbergena v $1974 \mathrm{~g}$. [Some results of radio echo-sounding of the glaciers of Spitsbergen in 1974]. Materialy Glyatsiologicheskikh Issledovaniy. Khronika. Obsuzhdeniya, Vyp. 26, p. 158-64.

Macheret, Yu. Ya. 1981. Forms of glacial relief of Spitsbergen glaciers. Annals of Glaciology, Vol. 2, p. 45-51.

Macheret, Yu. Ya., and Luchininov, V. S. 1973. Interpretatsiya rezul'tatov kontaktnoy radiolokatsionnoy s"yemki teplykh gornykh lednikov [Interpretation of the results of radio echo-sounding of temperate mountain-type glaciers]. Materialy Glyatsiologicheskikh Issledovaniy. Khronika. Obsuzhdeniya, Vyp. 22, p. 45-57.

Macheret, Yu. Ya., and Sukhanov, L. A. 1970. Opyt primeneniya impul'snogo vysotomera RV-10 dlya izmereniya tolshchiny "teplykh" gornykh lednikov s ikh poverkhnosti [Experience in the application of a RV-10 impulse altimeter for measuring the thickness of temperate mountain-type glaciers from their surface]. Materialy Glyatsiologicheskikh Issledovaniy. Khronika. Obsuzhdeniya, Vyp. 17, p. 60-72.

Macheret, Yu. Ya., and Zhuravlev, A. B. 1980. Radiolokatsionnoye zondirovaniye lednikov Shpitsbergena s vertoleta [Radio echo-sounding of Spitsbergen glaciers from helicopters]. Materialy Glyatsiologicheskikh Issledovaniy. Khronika. Obsuzhdeniya, Vyp. 37, p. 109-31.

Macheret, Yu. Ya., and others. 1980. Radiolokatsionnyye issledovaniya lednikov Shpitsbergena v 1977 g. [Radio echosounding investigations of Spitsbergen glaciers in 1977]. [By] Yu. Ya. Macheret, A. B. Zhuravlev, A. N. Gromyko. Materialy Glyatsiologicheskikh Issledovaniy. Khronika. Obsuzhdeniya, Vyp. 38, p. 279-86.

Miller, K. J. 1979. Under-ice volcanoes. Geographical Journal, Vol. 145, Pt. 1, p. 36-55.

Narod, B. B., and Clarke, G. K. C. 1980. Airborne UHF radio echo-sounding of three Yukon glaciers. Journal of Glaciology, Vol. 25, No. 91, p. 23-31.

Oelsner, C. 1966. Ergebnisse von Gravimetermessungen im Kingsbay-Gebiet (Westspitzbergen), Petermanns Geographische Mitteilungen, Jahrg. 110, 2. Quartalsht., p. 111-16. 
Paren, J. G., and Robin, G. de Q. 1975. Internal reflections in polar ice sheets. Journal of Glaciology, Vol. 14, No. 71, p. $251-59$.

Robin, G. de Q. 1975. Radio-echo sounding: glaciological interpretations and applications. Journal of Glaciology, Vol. 15, No. 73, p. 49-64.

Robin, G. de Q., and others. 1969. Interpretation of radio echo sounding in polar ice sheets, by G. de Q. Robin, S. Evans, and J. T. Bailey. Philosophical Transactions of the Royal Society of London, Ser. A, Vol. 265, No. 1166, p. 437-505.

Ryumin, A. K. 1967. Glyatsiologicheskiye i geomorfologicheskiye issledovaniya Tyan'-Shan'skoy ekspeditsii LGU v khrebte Terskey-Alatau [Glaciological and geomorphological investigations of the Tyan'-Shan' expedition of Leningrad State University in the Terskey-Alatau range]. Vestnik Leningradskogo Universiteta. Seriya Geologiya $i$ Geografiya, 1967, No. 6, p. 158-59.

Ryumin, A. K. 1972. Radiolokatsionnoye zondirovaniye lednika Abramova [Radio echo-sounding of Lednik Abramov]. Trudy Sredne-Aziatskogo Regional'nogo Nauchno-issledovatel'skogo Gidrometeorologicheskogo Instituta, Vyp. 65(80), p. 73-83.

Ryumin, A. K., and Zverev, V. B. 1969. Radiolokatsionnoye zondirovaniye gornykh lednikov [Radio echo-sounding of mountain-type glaciers]. Vestnik Leningradskogo Universiteta. Seriya Geologiya i Geografiya, 1969, No. 6. p. $152-60$.

Ryumin, A. K., and others. 1974. Stroyeniye lednika Abramova po dannym radiolokatsionnogo zondirovaniya [The structure of Lednik Abramov from radio echo-sounding data]. [By] A. K. Ryumin, V. K. Nozdryukhin, Yu. N. Yemel'yanov, V. A. Morev. Trudy Sredne-Aziatskogo Regional'nogo Nauchno-issledovatel'skogo Gidrometeorologicheskogo Instituta, Vyp. 14(95), p. 27-35.

Smith, B. M. E., and Evans, S. 1972. Radio echo sounding: absorption and scattering by water inclusion and ice lenses. Journal of Glaciology, Vol. 11, No. 61, p. 133-46.

Sukhanov, L. A. 1973. Izmereniye moshchnosti gornykh lednikov radiolokatsionnym metodom [Measurement of thickness of mountain-type glaciers by the radio echo-sounding method]. Materialy Glyatsiologicheskikh Issledovaniy. Khronika. Obsuzhdeniya, Vyp. 22, p. 58-65.

Troitskiy, L. S., and others. 1975 Oledeneniye Shpitsbergena (Svalbarda) [Glaciation of Spitsbergen (Svalbard)]. |By L. S. Troitskiy, Ye. M. Singer, V.S. Koryakin, V. A. Markin, V.I. Mikhalev. Moscow, Izdatel'stvo "Nauka".

Vasilenko, Ye. V., and others. 1980. Osobennosti radiolokatsionnogo zondirovaniya gornykh lednikov i postroyeniya spetsializirovannoy apparatury dlya glyatsiologicheskikh issledovaniy [Peculiarities of radio echo-sounding of mountain-type glaciers and of construction of specialized apparatus for glaciological investigations]. [By] Ye. V. Vasilenko, A. N. Gromyko, A. B. Zhuravlev, A. N. Kolyada, O. A. Lebedev, Yu. Ya. Macheret, N. P. Sidorov. Materialy Glyatsiologicheskikh Issledovaniy. Khronika. Obsuzhdeniya, Vyp. 38, p. 273-78.

Waite, A. H., jr. 1966. International expeditions in glacier sounding, 1963 and 1964. Canadian Journal of Earth Sciences, Vol. 3, No. 6, p. 887-92.

Watts, R. D., and England, A. W. 1976. Radio-echo sounding of temperate glaciers: ice properties and sounder design criteria. Journal of Glaciology, Vol. 17, No. 75, p. 39-48.

Watts, R. D., and others. 1975. Radio-echo sounding on South Cascade Glacier, Washington, using a longwavelength, mono-pulse source, by R. D. Watts, A. W. England, R. S. Vickers, and M. F. Meier. Journal of Glaciology, Vol. 15, No. 73, p. 459-61. [Abstract.]

Whillans, I. M. 1976. Radio-echo layers and the recent stability of the West Antarctic ice sheet. Nature, Vol. 264 , No. 5582, p. $152-55$.

Zagorodnov, V. S., and Zotikov, I. A. 1981. Kernovoye bureniye na Shpitsbergene [Ice core drilling on Spitsbergen]. Materialy Glyatsiologicheskikh Issledovaniy. Khronika. Obsuzhdeniya, Vyp. 40, p. 157-63.

Zhuravlev, A. B. 1976. Rezul'taty radiolokatsionnogo zondirovaniya lednika Obrucheva (Polyarnyy Ural) [Results of radio echo-sounding of Lednik Obruchev (Polyarnyy Ural)]. Materialy Glyatsiologicheskikh Issledovaniy. Khronika. Obsuzhdeniya, Vyp. 27, p. 132-36.

Zhuravlev, A. B. 1980. Opredeleniye ob"yema gornykh lednikov po dannym radiozondirovaniya s vertoleta [The determination of volume of mountain-type glaciers from radio echo-sounding data from helicopters]. Materialy Glyatsiologicheskikh Issledovaniy. Khronika. Obsuzhdeniya, Vyp. 37, p. 140-48. 